\title{
Synthesis and Biological Evaluation of Novel Substituted Pyrrolyl and Pyrazolyl Oxazolidinone Analogues
}

\author{
Jin-Sun Kwon, Chang-Sung Hong, Ju-Young Jung, Seung-Woo Yu, Jung-Su Ryu, Young-Jae Kim, \\ Jong-Min Yoon, Hong-Sub Lee, and Jae-Hoon Kang- \\ Research Laboratories, LLDONG Phamaceutical Co. Ltd., Hwaseong. Gyeonggi 415-170. Korea \\ ${ }^{*}$ E-mail: jhkangalildong.com \\ Received April 12, 2009, Accepted July 03. 2009
}

Key Worts: Oxazolidinone. Antibacterial, Linezolid

A number of life threatening infections caused by multidrugresistant Gram-positive pathogens have reached an alarming level in the hospitals and the community. ${ }^{1.2}$ Infections caused by these organisms pose a serious challenge to the scientific community and the need for an effective therapy has lead to a search for novel antibacterial agents. Oxazolidinones are a novel class of totally synthetic antimicrobial agents active against Gram-positive pathogenic bacteria including methicillin-resistant Staphylococctis atretus (MRSA). ${ }^{3.4}$ vancomycin-resistant Enterococcus faecium (VRE). ${ }^{5}$ and penicillin-resistant Streptococcus pneumoniae (PRSP) ${ }^{6,}$ Linezolid (1) is the first member of this class currently launched worldwide and available in both intravenous and oral formulations. Oxazolidinones have a unique mechanism for inhibiting bacterial protein synthesis at an early phase of translation by binding selectively to the central loop of domain of $23 \mathrm{~S}$ rRNA of $50 \mathrm{~S}$ ribosomal subunit. Oxazolidinones show no cross resistance with other classes of protein synthesis inhibitor. ${ }^{8.9}$ Linezolid is efficacious in treating skin and soft tissue infections. pneumonia and bacteremia. and it is particularly effective against infections caused by MRSA. VRE, and PRSP.

Recent studies by many research groups have focused on the development novel oxazolidinones based upon the replacement of the morpholine ring moiety of linezolid with various five-membered nitrogen-containing heterocycles (azoles). ${ }^{10,1]}$ In particular, the 3-cyano derivative 2 (PNU-172576) has excellent in vitro and in vivo activities. In light of these results, we emvisioned the design for synthesis of pyrrolyl and pyrazolyl derivatives 5 having an oxadiazole and alkoxyaninomethyl groups as a bioisostere of cyano group of 2 (PNU-172576). Several potent compounds were studied to find out their pharmacokinetic profiles and in vivo efficacies (Figure 1).

The general routes for the synthesis of the pyrrolyl and py razolyl oxazolidinone derivatives are outlined in Scheme 1 and 2 . The cyano intermediate 3 , which was prepared by a known procedure. "was treated with hydroxylanune to give anidoxime + in $90 \%$ yield. The subsequent cyclization of the amidoxime group with acetic anhydride. trifluoroacetic anhy-

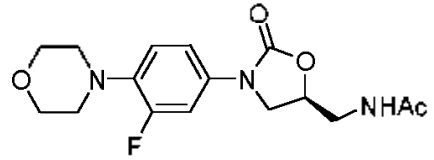

1(Linezolid)<smiles>N#Cc1cnn(-c2ccc(N3C[C@H](CNCCN)OC3=O)cc2F)c1</smiles>

2(PNU-172576)

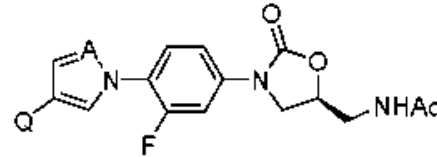

Q: axadiazolyl, alkoxyaminomethyl $\mathrm{A}: \mathrm{CH}, \mathrm{N}$

$\mathbf{5}$

Figure 1. Structures of oxazolidinone antibacterial agents.<smiles>N#Cc1ccn(-c2ccc(N3C[C@H](CN)OC3=O)cc2F)c1</smiles>

3<smiles>CCNC[C@H]1CN(c2ccc(-n3ccc(/C(N)=N/O)c3)c(F)c2)C(=O)O1</smiles>

4
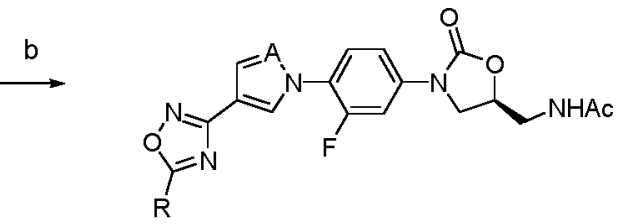

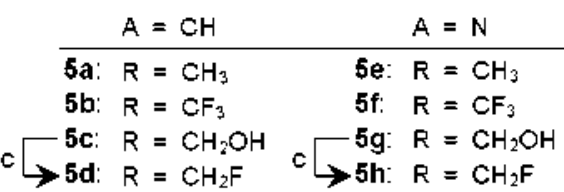

Scheme 1. Reagents and conditions: (a) $\mathrm{NH}_{2} \mathrm{OH} \cdot \mathrm{HCl}, \mathrm{NaHCO}_{3}, \mathrm{EtOH}$ : (b) $\mathrm{Ac}_{2} \mathrm{O}$ (for $\mathbf{5 a}$ and $\mathbf{5 e}$ ) or $\left(\mathrm{CF}_{3} \mathrm{CO}\right)_{2} \mathrm{O}$ (for $5 \mathrm{~b}$ and $\mathbf{5 f}$ ) or $\mathrm{ClC}(=\mathrm{O}$ ) $\mathrm{CO}_{2} \mathrm{Et}$ (for $\mathbf{5 c}$ and $\mathbf{5 g}$, and then $\mathrm{NaBH}_{4} / \mathrm{THF}$ ), Pyridine, Toluene; (c) DAST, $\mathrm{CH}_{2} \mathrm{Cl}_{2}$. 
<smiles>N#Cc1ccn(-c2ccc(N3C[C@H](CNCCN)OC3=O)cc2F)c1</smiles><smiles>NCCNCC1CN(c2ccc(-n3ccc(C=O)c3)c(F)c2)C(=O)O1</smiles>

6
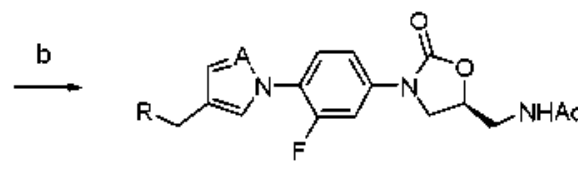

\begin{tabular}{|c|c|c|c|}
\hline & $\mathrm{A}=\mathrm{CH}$ & & $A=N$ \\
\hline & $\mathrm{R}=\mathrm{NHOH}$ & $5 \mathbf{5 k}$ & $\mathrm{R}=\mathrm{NHOH}$ \\
\hline
\end{tabular}

Scheme 2. Reagents and conditions: (a) Raney $\mathrm{Ni}, \mathrm{HCO}_{2} \mathrm{H}$ (b) i) $\mathrm{NH}_{2} \mathrm{OH} \cdot \mathrm{HCl}, \mathrm{K}_{2} \mathrm{CO}_{3}, \mathrm{CH}_{2} \mathrm{Cl}_{3} / \mathrm{MeOH}$ (for $5 \mathrm{i}$ and $5 \mathrm{k}$ ) or $\mathrm{NH}_{2} \mathrm{OCH} \cdot \mathrm{HCl}_{3}$ $\mathrm{K}_{2} \mathrm{CO}_{3}, \mathrm{CH}_{2} \mathrm{Cl}_{2} / \mathrm{MeOH}$ (for $\mathbf{5 j}$ and $\mathbf{5 l}$ ) ii) Borane-pyridine complex, $10 \% \mathrm{HCl}, \mathrm{MeOH}$

dride or ethyl chlorooxoacetate gave the oxadiazole derivatives 5a-h in $40 \sim 90 \%$ yield after chromatographic purification on silica gel.

Fluorination of alcohol (5c or $\mathbf{5} \mathbf{g}$ ) with diethy laminosulfur trifluoride (DAST) under low temperature condition afforded the corresponding fluorinated product ( 5 d or $5 \mathbf{h}$ ) in $50-66 \%$ yield.

Alkoxyaminomethỵl compounds 5i-5l were prepared by reductive amination of formyl intermediate 6 , which was afforded from oxidation of 3 with Raney $\mathrm{Ni} / \mathrm{HCOOH}$

Minimum inhibitory concentration (MC) values were determined by the Mueller-Hinton agar dilution method against Gram-positive strains including MRSA. VRE and PRSP. The activities of the compounds synthesized were compared with linezolid as a reference. $I n$ wivo efficacy for selected compounds were also evaluated against $S$. aureus infection model in mice. The MIC and $E D_{5 i}$ values of the pyrroyl and py razolyl analogues are presented in Table 1 .

All of pyrrolyl derivatives (5a-5d, 5i and $\mathbf{5 j}$ ) displayed good antibacterial activity. In contrast. most of pyrazolyl derivatives (5e-5h and 5k except for 5) exhibited comparable or slightly lower activity than linezolid. Therefore these findings led us to believe that the electronic character of the five-membered rings (pyrole versus pyrazole) may be playing a crucial role in the antibacterial activity of these analogues. In particular. compound 5 a with methyl group on the oxadiazole ring demon- strated MIC values 2-8 fold better than those of linezolid in all of the tested organisms including MRSA and VRE. And hydroxymethyl or fluoromethyl compounds (5c, 5d) also showed 16-32 fold excellent activities than linezolid against penicillinsusceptible. Streptococcus pneumonice. By comparing activities of methoxyaninomethyl (5j and $\mathbf{5}$ ) with oxadiazole (5a-5d and 5e-5h) as a bioisostere of cyano group. it could be found that non-rigid methoxyaminomethyl derivatives were comparable to that of the corresponding rigid oxadiazolyl derivatives. Compound 5e $\left(E_{5 i)}=5 \sim 8 \mathrm{mg} / \mathrm{kg}\right.$ ). py razolyl analogue having methyl oxadiazole displayed an oral efficacy comparable to that of linezolid $\left(\mathrm{ED}_{5 \mathrm{il}}=4.54 \mathrm{mg} / \mathrm{kg}\right.$ ). whereas compounds $5 \mathbf{a}$. 5b and $5 \mathbf{d}$ showed lower in wivo efficacy. Among these analogues. compound $\mathbf{5 j}$. containing non-rigid alkoxyaminomethyl exhibited excellent in vitro activity $(\mathrm{MIC}=0.1 \sim 0.8 \mu \mathrm{g} / \mathrm{mL}$ ) and $i n$ vivo efficacy $\left(\mathrm{ED}_{5 \mathrm{i}}=2.75 \mathrm{mg} / \mathrm{kg}\right)$.

The single-dose pharmacokinetic profiles of some active compounds in male Sprague-Dawley rats are summarized in Table 2. After oral administration. the compound 5a showed better results than the linezolid. particularly outstanding in AUC and $\mathrm{t}_{1: 2}$

In conclusions. a series of new pyrrolyl and pyrazolyl oxazolidinones have been synthesized, and their in vitro and in vivo antibacterial activities were evaluated against Gram-positive organisms including the resistant strains of Staphylococci. Ente-

Table 1. In vitro $(\mathrm{MIC}, \mu \mathrm{g} / \mathrm{mL})$ and $i n$ vivo $\left(\mathrm{ED}_{\mathrm{s}_{0}}, \mathrm{mg} \mathrm{g} / \mathrm{kg}\right.$ ) antibacterial activity

\begin{tabular}{|c|c|c|c|c|c|c|c|c|c|c|c|}
\hline \multirow{2}{*}{ Compd } & \multirow{2}{*}{$\mathrm{R}$} & \multirow[b]{2}{*}{ A } & \multicolumn{8}{|c|}{ MC $(\mu \mathrm{g} / \mathrm{mL})$ (microorganism $)^{a}$} & \multirow{2}{*}{$\begin{array}{c}E D_{s(1} \\
(\mathrm{mg} / \mathrm{kg})^{c}\end{array}$} \\
\hline & & & S.a 1 & S.a 2 & $\mathrm{MRSA}^{b}$ & $\mathrm{MSSA}^{t}$ & VRE. $\mathrm{f}^{b}$ & VSE. $f^{d \prime}$ & $\mathrm{PNSP}^{b}$ & PSSP $^{b}$ & \\
\hline $5 a$ & $\mathrm{CH}_{3}$ & $\mathrm{CH}$ & 0.4 & 0.4 & 0.8 & 0.8 & 0.8 & 0.2 & 0.1 & 0.1 & $>10$ \\
\hline $5 b$ & $\mathrm{CF}_{3}$ & $\mathrm{CH}$ & 0.4 & 0.8 & 1.6 & 1.6 & 1.6 & 0.8 & 0.4 & 0.4 & $>10$ \\
\hline $5 c$ & $\mathrm{CH}_{2} \mathrm{OH}$ & $\mathrm{CH}$ & 0.8 & 0.4 & 0.8 & 0.4 & 0.8 & 0.2 & 0.05 & 0.025 & \\
\hline $5 d$ & $\mathrm{CH}_{*} \mathrm{~F}$ & $\mathrm{CH}$ & 0.8 & 0.4 & 0.8 & 0.2 & 0.4 & 0.2 & $<0.025$ & $<0.025$ & $>10$ \\
\hline $5 e$ & $\mathrm{CH}_{3}$ & $\mathrm{~N}$ & 3.1 & 1.6 & 3.1 & 1.6 & 1.6 & 1.6 & 1.6 & 0.4 & $5-8$ \\
\hline $5 f$ & $\mathrm{CF}_{3}$ & $\mathrm{~N}$ & 12.5 & 12.5 & 25 & 12.5 & 12.5 & 6.3 & 12.5 & 6.3 & \\
\hline $5 g$ & $\mathrm{CH}_{2} \mathrm{OH}$ & $\mathrm{N}$ & 3.1 & 0.8 & 3.1 & 1.6 & 1.6 & 0.8 & 1.6 & 0.8 & \\
\hline 5h & $\mathrm{CH}_{\star} \mathrm{F}$ & $\mathrm{N}$ & 3.1 & 3.1 & 3.1 & 3.1 & 1.6 & 1.6 & 0.8 & 0.4 & \\
\hline $5 i$ & $\mathrm{NHOH}$ & $\mathrm{CH}$ & 0.8 & 1.6 & 3.1 & 1.6 & 0.8 & 0.8 & 0.2 & 0.4 & \\
\hline $5 j$ & $\mathrm{NHOCH}_{3}$ & $\mathrm{CH}$ & 0.4 & 0.8 & 0.8 & 0.4 & 0.4 & 0.4 & 0.4 & 0.1 & 2.75 \\
\hline $5 \mathbf{k}$ & $\mathrm{NHOH}$ & $\mathrm{N}$ & 3.1 & 1.6 & 3.1 & 1.6 & 1.6 & 0.8 & 0.4 & 0.4 & \\
\hline 5l & $\mathrm{NHOCH}_{3}$ & $\mathrm{~N}$ & 0.8 & 1.6 & 1.6 & 0.8 & 1.6 & 0.8 & 0.2 & 0.1 & \\
\hline 1 & & & 1.6 & 1.6 & 3.1 & 1.6 & 1.6 & 1.6 & 0.8 & 0.4 & 4.54 \\
\hline
\end{tabular}

Organisms: S.a 1. Staplnlococus auretus SG511: S.a 2. Staphlococcus awreus 503: MRSA. methicillin-resistant Staphylococcus anreus: MSSA. methicillin-susceptible Staphnococcus antens; VRE.f. vanconvcin-resistant Enterococcus faecinm. VSE.f. vanconycin-susceptible Enterococens faecinm: PNSP. penicillin-non susceptible Streptococcus pheumonat. PSSP, penicillin-susceptible Streptococcus phe University College of Medicine. Seoul, Korea. 'ED ${ }_{50}$ is the amount of drug required after oral administration (mg $k g$ day') to cure 50 o. of infected mice subjected to a lethal sy stenic infection of $S$. anter. $\mathrm{SG} 51 \mathrm{l}$. 
Table 2. Single dose phannacokinetic parameters"

\begin{tabular}{|c|c|c|c|c|c|}
\hline Compd & $\operatorname{Dose}^{b}(\mathrm{mg} / \mathrm{kg})$ & $T_{\max }{ }^{c}(\min )$ & $\mathrm{C}_{\max }{ }^{d}(u g \mathrm{~g} / \mathrm{mL})$ & $\mathrm{AUC}^{e}(t \mathrm{~g} \cdot \mathrm{min} / \mathrm{mL})$ & $\mathrm{T}_{1: i^{\prime}}$ (min) \\
\hline $5 a$ & 15 & 180 & 5.1 & 4296.7 & 969.6 \\
\hline $5 c$ & 15 & $\mathrm{NA}^{\circ}$ & NA & NA & NA \\
\hline $5 d$ & 15 & 60 & 4.881 & 741.9 & 102.2 \\
\hline $5 e$ & 15 & 60 & 9.2 & 1809.7 & 110.7 \\
\hline $5 \mathbf{j}$ & 15 & 30 & 5.826 & 1191.8 & 54.9 \\
\hline 1 & 15 & 30 & 4.431 & 1340.9 & 169.5 \\
\hline
\end{tabular}

"Each compound was dissolyed in $1^{\circ} \mathrm{C}$ CMC solution and orally administered to SD rat. " $\mathrm{N}$ ' $=5$. "Time at which $\mathrm{C}_{\max }$ achieved. "Maximum plasma concentration. ${ }^{e}$ The total area under the plasma concentration-time curve form time zero to time infinity. 'Harmonic mean apparent terminal disposition half-life. NA = Not Absorbed

rococci and Pneumococci. Some of these analogues exhibited more potent $i n$ vitro antibacterial activities than those of linezolid. Especially. compound 5j, containing non-rigid alkoxyaminomethyl as a bioisostere of cyano group on pyrrole ring exhibited excellent in vitro activity $(\mathrm{MIC}=0.1-0.8 \mu \mathrm{g} / \mathrm{mL})$, in vivo efficacy ( $E D_{51}=2.75 \mathrm{mg} / \mathrm{kg}$ ) and favorable pharmacokinetics. With these results in hand further optimization of oxazolidinone analogues for $i n$ witro and in wo activities is in progress.

\section{Experimental Section}

General. NMR spectra were recorded on a Bruker Avance II $400\left(100.63 \mathrm{MHz}\right.$ for ${ }^{13} \mathrm{C}$ and $400.13 \mathrm{MHz}$ for ${ }^{1} \mathrm{H}$ ). Chemical shifts are indicated in $\delta$ values (ppm) downfield from internal TMS. IR spectra were recorded on a Jasco FT/IR 4100 spectrophotometer. Mass spectra were recorded on a Finnigan LC/ MSD. The products were analyzed with a Hypersil Gold C 18 column $(2.1 \times 100 \mathrm{~mm}, 3.0 \mathrm{tm}$ particles) using the linear gradient condition. The flow rate was $0.2 \mathrm{~mL} / \mathrm{min}$, and the eluent was monitored at $260 \mathrm{~nm}$. The mass spectral mode of operation was positive ion electrospray (API-ES).

$N$-((S)-3-\{3-Fluom-4-[3-( $N$-hydoxycarbamimidoyl)-pymo]1-yl]-phenyl; -2-0x0-0xazolidin-5-ylmethyl)-acetamide (4): To a solution of 3 ( $428 \mathrm{mg} .1 .25 \mathrm{mmol}$ ) in $\mathrm{EtOH}(4.12 \mathrm{~mL}$ ) were added hydroxylamine hydrochloride ( $435 \mathrm{mg} .6 .25 \mathrm{mmol}$ ) and $\mathrm{NaHCO}_{3}(525 \mathrm{mg} .6 .25 \mathrm{mmol})$. The mixture was heated under reflux overnight. The mixture was allowed to cool to room temperature and then the solvent was evaporated under reduced pressure. The resulting precipitate was collected by filtration. washed with water and dried under vacuum to give the product (424 mg. 90\%). ${ }^{\text {H }}$ NMR (400 MHz, DMSO- $\left.d_{6}\right) \delta 9.13$ (1H. s), 8.28 (1H. dd). 7.73 (1H. dd). 7.62 (1H. dd). 7.50 (1H. s) 7.41 (1H. dd). 7.10 (lH, s). 6.51 (lH, dd). $5.56(2 \mathrm{H}, \mathrm{s}) .4 .79(1 \mathrm{H}, \mathrm{m})$. 4.19 (1H. t). 3.88 (1H, dd), 3.45 (2H. dd), 1.84 (3H. s); ${ }^{13}$ C NMR $\left(100.6 \mathrm{MHz}, \mathrm{CDCl}_{3}\right) \delta 170.0,155.1,154.0,152.7 .147 .6$. $137.7,125.1,121.8$. 119.4. 114.2. 109.7. 107.7. 106.2, 71.7. 47.2. 41.3. 22.4: IR (KBr) 1737, 1631, 1592, 1527, 1411. 1224. $1201 \mathrm{~cm}^{-1}$

$N$-((S)-3-\{3-Fluon-t-[3-(5-methyl-[1,2,4]oxadiazol-3-yl)pynol-1-yl]-phenyl\}-2-oxo-oxazolidin-5-ylmethyl)-acetamide (5a): To a solution of $4(30 \mathrm{mg}, 0.08 \mathrm{mmol})$ in pyridine $(1.1 \mathrm{~mL})$ was added acetic anhydride ( $11 \mu \mathrm{L} .0 .117 \mathrm{mmol}$ ). The mixture was heated under reflux overnight and then was allowed to cool to room temperature. The solution was diluted with water and extracted with $\mathrm{CH}_{2} \mathrm{Cl}_{2}$. The combined organic layyers were washed with $2 \mathrm{~N} \mathrm{HCl}$ and brine. dried and concentrated. Chrontatographic purification (ethyl acetate/hexane/methanol = $4: 4: 1)$ afforded 5 a $(28.4 \mathrm{mg} .89 \%)$ of the desired material. ${ }^{1} \mathrm{H}$ NMR (400 MHz. $\left.\mathrm{CDCl}_{3}\right)$ ô $7.68(2 \mathrm{H} . \mathrm{dd}), 7.42(1 \mathrm{H}, \mathrm{dd}), 7.35$ (lH, dd). $7.28(\mathrm{lH}, \mathrm{dd}) .7 .05(\mathrm{lH}, \mathrm{s}) .6 .82(\mathrm{lH}, \mathrm{dd}) .4 .82(\mathrm{lH}, \mathrm{m})$. $4.11(1 \mathrm{H}, \mathrm{t}) .3 .84(\mathrm{lH}, \mathrm{dd}) .3 .65(2 \mathrm{H}, \mathrm{dd}) .2 .63(3 \mathrm{H} . \mathrm{s}) .2 .03(3 \mathrm{H}$. s): ${ }^{12} \mathrm{C} \mathrm{NMR}\left(100.6 \mathrm{MHz}, \mathrm{CDCl}_{3}\right)$ ò $175.9 .171 .3,164.9 .156 .1$. $154.2,153.7,137.6,125.1,124.4 .122 .7,113.8,112.8,109.2$, 107.3, 72.1. 47.4. 41.8, 23.1. 12.3: IR (KBr) 1739, 1531 , $1411,1225,1198 \mathrm{~cm}^{-1}$ : MS $399\left(\mathrm{M}^{-}\right)$.

$N-((\mathrm{S})-3-\{3-F l w o r 0-4-[3-(5-h y d r o x y m e t h y l-[1,2,+]$ oxadiazo]3-yl)-pynol-1-yl]-jphenyl;-2-0xo-oxazolidin-5-ylmethyl)-acetamide (5c): To a solution of 4 (62 ng, $0.16 \mathrm{~mm}$ ol) in toluene ( $1 \mathrm{~mL}$ ) were added pyridine ( $40 \mu \mathrm{L} .0 .49 \mathrm{~nm}$. $)$ and ethyl chlorooxoacetate $(27.8 \mu \mathrm{L}, 0.25 \mathrm{mmol})$ at $0^{\circ} \mathrm{C}$. After stirring $30 \mathrm{~min}$. the mixture was allowed to warm to room temperature and stirred for $\mathrm{l} \mathrm{h}$. Then. the mixture was heated under reflux overnight and was allowed to cool to roon temperature. The solution was diluted with water and extracted with $\mathrm{CH}_{2} \mathrm{Cl}_{2}$. The combined organic layers were washed with $2 \mathrm{~K} \mathrm{HCl}$ and brine, dried, and concentrated. Chromatographic purification (ethỵl acetate/hexane/methanol $=4: 4: 1$ ) afforded ethỵ lcarboxy intermediate $(30.8 \mathrm{mg}, 42 \%)$. And to a solution of the intermediate ( $42.3 \mathrm{mg}, 0.09 \mathrm{mmol})$ in $\mathrm{THF}$ ( $1 \mathrm{~mL}$ ) was added $\mathrm{NaBH}_{4}$ (6.8 mig. $0.18 \mathrm{mmol}$ ) at $0^{\circ} \mathrm{C}$. The mixture was stirred for $3 \mathrm{~h}$ and then diluted with water and extracted with $\mathrm{CH}_{2} \mathrm{Cl}_{2}$. The combined organic layers were washed with water and brine. dried. and concentrated. Chromatographic purification (ethyl acetate/hexane/methanol $=4: 4: 1)$ afforded $5 \mathrm{c}(16 \mathrm{mg} .43 \%)$ of the desired material. ${ }^{\mathrm{H}} \mathrm{H} \mathrm{NMR}\left(400 \mathrm{MHz}, \mathrm{DMSO}-d_{6}\right)$ of 8.29 (lH. dd). 7.75 (3H. dd). 7.46 (lH. dd). 7.31 (lH. dd). 6.75 $(\mathrm{lH}, \mathrm{s}), 6.02(\mathrm{lH}, \mathrm{s}) .4 .77(2 \mathrm{H}, \mathrm{s}) .4 .75(1 \mathrm{H}, \mathrm{m}) .4 .18(\mathrm{lH}, \mathrm{t})$. 3.79 (1H. dd). 3.44 (2H. dd), $1.85(3 \mathrm{H}, \mathrm{s}) ;{ }^{13} \mathrm{C}$ NMR (100.6 MHz, DMSO- $\left.d_{6}\right) \delta$ o $178.4 .170 .0,164.1,155.3,154.0 .152 .9$. $138.4,125.8,123.9,122.7,114.1,111.8 .108 .5 .106 .3 .71 .8$, $55.0 .47 .2,41.3 .22 .4$ : $\mathbb{R}(\mathrm{KBr}) 17+1.1531 .1+15,1227.1199$ $\mathrm{cm}^{-1}: \mathrm{MS}+15\left(\mathrm{M}^{+}\right)$.

$N$-((S)-3-\{3-Fluono-t-[3-(5-fluo romethyl-[1,2,4] oxadliazol3-yl)-pyıol-1-yl]-[henyl\}-2-0x0-0xazolidin-5-ylmethyl)-acetamike (5d): To a solution of $5 \mathrm{c}\left(63.8 \mathrm{ng}, 0.153 \mathrm{~nm}\right.$ ol) in $\mathrm{CH}_{2} \mathrm{Cl}_{2}$ ( $\mathrm{mL}$ ) was added diethy laminosulfur trifluoride (DAST) $(26.7 \mu$ L, $0.202 \mathrm{nmol})$ in $\mathrm{CH}_{2} \mathrm{Cl}_{2}(3 \mathrm{~mL})$ at $-78^{\circ} \mathrm{C}$. The mixture was stirred for $2 \mathrm{~h}$ at $-78^{\circ} \mathrm{C}$. Stirring was continued for $1 \mathrm{~h}$ while 
the reaction mixture was allowed to wann at room temperature. The mixture was poured into water and extracted with $\mathrm{CH}_{2} \mathrm{Cl}_{2}$. The combined organic layers were washed with water and brine, dried. and concentrated. Chromatographic purification (ethyl acetate/hexane/methanol $=4: 4: 1$ ) afforded $5 d$ $\left(34.8 \mathrm{mg}, 54 \%\right.$ ) of the desired material. ${ }^{\mathrm{H}} \mathrm{H}$ NMR $(400 \mathrm{MHz}$. $\left.\mathrm{CDCl}_{3}\right)$ ô $8.30(\mathrm{lH}, \mathrm{dd}) .7 .82(\mathrm{lH}, \mathrm{dd}) .7 .7+(2 \mathrm{H}, \mathrm{dd}) .7 .46$ (1H. dd). $7.31(1 \mathrm{H} . \mathrm{dd}), 6.78(1 \mathrm{H}, \mathrm{s}) .5 .88(1 \mathrm{H}, \mathrm{s}), 5.77(1 \mathrm{H}$. s), $4.75(1 \mathrm{H}, \mathrm{m}) .4 .20(1 \mathrm{H}, \mathrm{t}) .3 .79(\mathrm{lH} . \mathrm{dd}) .3 .45(2 \mathrm{H} . \mathrm{dd})$. $1.8+(3 \mathrm{H} . \mathrm{s}):{ }^{13} \mathrm{C}$ NMR $\left(100.6 \mathrm{MHz}, \mathrm{CDCl}_{3}\right) \delta 172.3 .171 .2$. $165.2,156.2 .154 .1,153.7 .137 .8 .125 .3,123.8 .113 .8,112.1$, $109.3 .107 .3 .73 .5,72.2 .61 .9,47.4 .+1.9,29.7 .23 .1: \mathbb{R}(\mathrm{KBr})$ 1732. 1657, 1608, 1531,1417. $1230 \mathrm{~cm}^{-1}$; $\mathrm{MS}+17\left(\mathrm{M}^{-}\right)$.

$\mathrm{N}$-\{ (S)-3-[3-Fluoro-4-(3-fomyl-pymo]-1-y])-phenyl]-2ox0-0xazolidin-5-yl methyl -acetamide (6): To a solution of 3 (l g. $2.92 \mathrm{mmol}$ ) in formic acid (6 $\mathrm{mL}$ ) was added Raney nickel $(2 \mathrm{~g})$ in formic acid $(6 \mathrm{~mL})$ at $0^{\circ} \mathrm{C}$. The mixture warmed to $70^{\circ} \mathrm{C}$ and stirred for $3 \mathrm{~h}$. The Raney nickel was removed by celite filtration and the filtrate was neutralized with ammonia solution. The solution was diluted with water and extracted with $\mathrm{CH}_{2} \mathrm{Cl}_{2}$. The combined organic layers were washed with brine dried, and concentrated. The residue was purified by silica gel column chromatography (ethyl acetate/hexane/metha$\mathrm{nol}=4: 4: 1)$ to afford $6(820 \mathrm{mg} .81 \%)$ of the desired material. ${ }^{l} \mathrm{H}$ NMR (400 MHz, DMSO-d $)$ ò $9.79(1 \mathrm{H}, \mathrm{s}) .8 .28(1 \mathrm{H}, \mathrm{t})$. 8.27 (lH, dd). $7.68 \sim 7.72(2 \mathrm{H}, \mathrm{m}) .7 .45(\mathrm{lH}, \mathrm{dd}) .7 .29(\mathrm{lH}, \mathrm{s})$. $6.68(1 \mathrm{H}, \mathrm{dd}) .477(1 \mathrm{H}, \mathrm{m}), 4.18(1 \mathrm{H}, \mathrm{t}) .3 .78(1 \mathrm{H}, \mathrm{dd}) .3 .40 \sim$ $3.45(2 \mathrm{H} . \mathrm{m}), 1.84(3 \mathrm{H}, \mathrm{s}) ;{ }^{13} \mathrm{C} \mathrm{NMR}\left(100.6 \mathrm{MHz}, \mathrm{CDCl}_{3}\right)$ ò $185.4,170.0 .155 .5,154.0,153.1 .138 .9,131.2 .127 .3,124.9$. 122.2, 114.1. 107.8, 106.3, 71.8, 47.2, 41.3. 22.4; IR (KBr) 1735, 1681, 1652,1525,1384.1213 $\mathrm{cml}^{-1}$

$N$-\{ (S)-3-[3-Fluoro-4-(3-hydroxyaminomethyl-py mo]-1yl)-phenyl]-2-0x0-0xazolidin-5-ylmethyl -acetamide (5j): To a solution of 6 (785 mg. $2.27 \mathrm{mmol}$ ). methoxylamine hýdrochloride $(285 \mathrm{mg}, 3.41 \mathrm{mmol}$ ) and potassium carbonate $(471 \mathrm{mg}$. $3.4 \mathrm{lmmol}$ ) were stirred in methanol/methy lene chloride ( $1: \mathrm{l})$ $(18 \mathrm{~mL} / 18 \mathrm{~mL}$ ) overnight. And then the resulting precipitate was collected. washed with water and dried under vacuum to give the methoxyimine intermediate ( $839 \mathrm{mg} .99 \%$ ). And to a solution of methoxyinine internediate $(8.39 \mathrm{mg} .2 .24 \mathrm{mmol})$ in methanol ( $18.2 \mathrm{~mL}$ ) was added borane pyridine complex $(987 \mu \mathrm{L})$ at $0^{\circ} \mathrm{C}$. The misture was stirred for $5 \mathrm{~min}$ and added
$10 \% \mathrm{HCl}(11.3 \mathrm{~mL})$ at $0^{\circ} \mathrm{C}$. Stirring was continued for $15 \mathrm{~min}$ while the reaction mixture was allowed to room temperature. The solution was basified with saturated sodium bicarbonate and extracted with $\mathrm{CH}_{2} \mathrm{Cl}_{2}$. The combined organic layers were washed with brine. dried. and concentrated. The residue was purified by silica gel column cluromatography (ethyl acetate/ hexane/methanol $=4: 4: 1)$ to afford $5 \mathbf{j}(783 \mathrm{mg} .93 \%$ ) of the desired material. ${ }^{1} \mathrm{H} \mathrm{NMR}\left(400 \mathrm{MHz}, \mathrm{CDCl}_{3}\right)$ ô 7.58 (1H. dd), $7.33(1 \mathrm{H}, \mathrm{dd}), 7.29(1 \mathrm{H}, \mathrm{dd}), 6.93(1 \mathrm{H}, \mathrm{dd}), 6.90(1 \mathrm{H}, \mathrm{dd})$ $6.31(\mathrm{lH}, \mathrm{s}), 4.8 \mathrm{l}(\mathrm{lH}, \mathrm{m}), 4.05$ (lH, dd). 3.99 (lH. s). 3.82 (1H. dd), 3.67 (2H. dd), 3.57 (1H.s), 2.04 (1H. s): ${ }^{12} \mathrm{C}$ NMR $\left(100.6 \mathrm{MHz}, \mathrm{CDCl}_{3}\right) \delta 170.0,155.0,153.9,152.5,137.2$, $125.0,123.3,121.8,119.8,114.1,110.7 .106 .3 .71 .7 .60 .6 .47 .6$. 47.2, 41.3, 22.4: R (KBr) 1725, 1654, 1531, 1421, 1230, 1195 $\mathrm{cm}^{-1}$ : MS $376\left(\mathrm{M}^{+}\right)$.

Acknowledgments. This work was supported by the Korea Ministry of Knowledge Econony

\section{References}

1. Mitscher, L. A.; Pillai, S. P.: Gentry, E. I.: Shankel, D. M. Med. Res. Rev. 1999, 19,477.

2. Willians, D. H.: Bardsley, B. Angew: Chem. Int Ed. 1999, 38 , 1173

3. Khare, M.; Keady, D. Exper. Opin. Phamacother 2003, $7,165$.

4. Hamilton-Miller, I. M. Infection 2002, 30, 118 .

5. Lam, S.; Singer, C.; Tucci, V.; Morthland, V. H.; Pfaller, M. A.; Isenberg, H. D. Ant J Infect. Control. 1995, 23, 170

6. Nicolall. D. J. Antimicrob. Chemother. 2002, 50,61.

7. Adam, D. J.Antmicrob. Chemother, 2002, 50, 1

8. Aoki, H.; Ke, L; Poppe, S. M: Poel, T. I.; Weaver, E. A: Gadwood, R. C.; Thomas, R. C; Shinabarger, D. L.; Gonaza, M. C. Antmicrob. Agents Chemother 2002, $\$ 6,1080$.

9. Hwnag, J. M.; Yeom, S. H., Jung, K. Y. Bull Korean Chem. Soc. $2007,28,821$

10. Genin, M. T; Allwine, D. A ; Anderson, D. J ; Barbachyn, M. R: Emmert, D. E.; Ganmon, S. A.: Graber, D. R.; Grega, K. C.: Hester, J. B.; Hutchinson, D. K.: Morris, J.: Reischer, R. J : Ford, C. W.; Zurenko, G. E.: Hamel, J. C.: Schaadt, R. D.; Stapert, D.; Yagi, B. H. J. Hed. Chent 2000, t3, 953.

11. Genin, M. J.; Hutchinson, D. K.; Allwine, D. A.; Hester, J. B.; Emmert, D. E.: Garmon, S. A.: Ford, C. W.: Zurenko, G. E.; Hamel, I. C.: Schaadt, R. D.: Stapert, D.: Yagi, B. H.; Friis, I. M.: Shobe, E. M: Adams, W. J. J. Hed Chem. $1998,41,5144$. 